\title{
EXCHANGES OF SODIUM AND POTASSIUM IN FAMILIAL PERIODIC PARALYSIS ${ }^{1}$
}

\author{
By T. S. DANOWSKI, J. R. ELKINTON, B. A. BURROWS, AND A. W. WINKLER 2 \\ (From the Department of Internal Medicine, Yale University School of Medicine, New Haven)
}

(Received for publication August 7, 1947)

The constant association of a fall in concentration of serum potassium with attacks of muscular weakness, plus the relief of the weakness by the administration of potassium salts, have clearly indicated that familial periodic paralysis involves a defect in potassium metabolism. The nature of this is not completely understood.

Following the observation that the concentration of potassium in serum was lowered at the time of paralysis $(1,2)$, a number of other investigators studied potassium exchanges in this condition to ascertain the route of removal of potassium from serum and extracellular fluid. It has been found that the urinary excretion of potassium prior to and during attacks of paralysis, with but 1 exception, was minimal, and hence the lowered concentration of this cation must result from a shift into cells ( 3 to 7 ). Only during a water diuresis preceding an attack did Gammon and co-workers (6) find an increased excretion of potassium in the urine. It has been suggested that an abnormal demand for potassium in muscle cells is present in this condition (7). The production of lowered concentrations of serum potassium and of paralysis by the administration of carbohydrate, insulin, or epinephrine has also led to the hypothesis that potassium may be moved from extracellular fluid into cells of the liver or other tissues of the body during glycogenesis or carbohydrate combustion.

Ferrebee, Gerity, Atchley, and Loeb (8) have reported the results of an extensive metabolic study of a patient with this disease. They confirmed the finding that potassium excretion diminished coincidently with the fall in serum concentration during an attack, and found erratic fluctuations in excretion of potassium and sodium between attacks. They did not, however, quantitate the exchanges of potassium and sodium between

1 Aided by a grant from the Fluid Research Fund of Yale University.

2 Deceased, June 26, 1947. the extracellular and intracellular phases of the body fluids. This has been done, therefore, in the studies reported in this paper in the hope that the magnitude and the direction of the exchanges of these cations might help further to elucidate the abnormality of potassium metabolism which is present in this disease.

\section{EXPERIMENTAL PROCEDURE AND METHODS}

The patients studied were 2 of the 3 cases of familial periodic paralysis which have been diagnosed in the New Haven Hospital since 1921. Patient R. B. was a 29year-old white man who had had attacks of muscular weakness every 2 to 4 weeks since the age of 18 years. One sister was subject to similar attacks. Patient D. D. was a 34-year-old white man who had had intermittent attacks of paralysis since the age of $\mathbf{1 5}$ years. One halfbrother was said to have similar but less severe symptoms. In both patients the attacks usually began during sleep in the early morning hours and were relieved by ingestion of potassium. On admission and during the attacks the patients' physical examinations were negative except for motor weakness and diminished to absent deep reflexes.

The quantitative data on Patient $R$. B. were obtained during recovery from a spontaneous attack of generalized paralysis. In the first period of 3 hours $\mathrm{KCl}$ was given by mouth; in the succeeding period of 16 hours the patient took food and water. In Patient D. D. the quantitative study extended over a period of 4 days, during which an attack of paralysis was induced by withdrawal of the maintenance dose of $\mathrm{KCl}$ and the administration of large doses of carbohydrate. The patient received no other food during the entire study. Recovery was effected by giving $\mathrm{KCl}$ intravenously and orally.

The patients were weighed and blood was taken for analysis at the beginning and end of each period. Concentrations of $\mathrm{Cl}, \mathrm{Na}$, and $\mathrm{K}$ in serum were determined in both subjects as were $\mathrm{Cl}, \mathrm{Na}$, and $\mathrm{K}$ balances. In $\mathrm{Pa}$ tient D. D., there were measured as well nitrogen balances and also the concentrations in blood of nonprotein nitrogen and of sugar.

The electrolyte content of food eaten by the first subject was calculated by means of Sherman's tables (9); the milk and lemon juice present in the sucrose-lactose drink taken by Patient D. D., and a stool which he passed following oral $\mathrm{KCl}$, were analyzed for $\mathrm{Na}, \mathrm{K}, \mathrm{Cl}$, and nitrogen.

In Patient R. B. sodium in serum, and potassium in 
serum and urine were determined by the method of Hald (10) ; sodium in urine, by the method of Butler and Tuthill (11). In the studies on Patient D. D., sodium and potassium concentrations were measured by means of the flame photometer (12). The whole blood, milk, and stool were first ashed at $550^{\circ}$ to $650^{\circ} \mathrm{C}$. The methods used for the determination of chloride, blood sugar, nonprotein nitrogen, urine nitrogen, the relative blood cell volume, the volume of distribution of mannitol, and the water content of serum and whole blood have been listed in previous publications $(13,14)$.

\section{METHOD OF CALCULATION}

The method of calculation has been detailed in previous publications $(13,15,16)$. The total water balance was calculated from the change in weight corrected for the solids lost and from the metabolic mixture. The change in extracellular fluid volume was calculated from the balance of chloride and the changes in its concentration in serum. In Patient D. D. the volume of the extracellular fluid was measured by the volume of distribution of mannitol $\mathbf{3}$ in the middle of the experiment. The change in chloride space was then calculated from this value both forward and backward in time instead of assuming an initial extracellular volume. Changes in intracellular fluid volume were taken as the difference between the volumes of total water and extracellular fluid.

The changes in, or balance of intracellular sodium and potassium, which were independent of the building up or breaking down of tissues (in excess of nitrogen), were taken to be the balances of these 2 ions remaining after the total balances were corrected for increments or decrements associated with the extracellular fluid and with the balance of protein. The change in total osmotically active base is taken to be the discrepancy between the theoretical balance of sodium and potassium, calculated from the water balance and the change in concentration of serum sodium, and the observed total balance of sodium plus potassium.

\section{RESULTS}

The analytical and derived data are given in Tables I, II, and III, and in Figure 1.

Exchanges of potassium. In Patient R. B., during the immediate period of recovery produced by the oral administration of $\mathrm{KCl}$, potassium was taken up into both extracellular and intracellular phases, and the extracellular concentrations of potassium rose to a normal level. During the subsequent 16 hours during which little potassium was given, the extracellular potassium was retained, but the cellular increment for the most part was lost in the urine.

In Patient D. D., during the first 26 hours of

3 The mannitol was supplied through the courtesy of the Medical Research Division of Sharp and Dohme, Inc. the experiment following the withdrawal of $\mathrm{KCl}$ and the ingestion of large doses of carbohydrate, loss of potassium in the urine resulted in a small negative potassium balance. Most of this potassium was cellular. During the subsequent period from hours 26 to 62 , at which time the peak of paralysis was reached, this negative balance persisted, but the deficit of cell potassium which had developed during the period of hours 0 to 26 was cancelled by transfer of potassium from the extracellular space. This transfer of potassium from the extracellular to the intracellular phase with the associated decline in extracellular potassium concentration to 2.2 m.eq. per liter coincided with the onset of muscular paralysis.

Following the intravenous administration of $\mathrm{KCl}$ (hour 62 to 68) a moderately large amount of potassium entered the intracellular phase but the extracellular potassium deficit was only partially cancelled and some paralysis persisted. When more $\mathrm{KCl}$ had been given orally (hours 68 to 74), the balance of extracellular potassium became positive, both the concentration and amount of extracellular potassium increased, and simultaneously the muscular weakness disappeared. At the end of the study (hour 98) the amount of extracellular potassium was approximately the same as it had been initially, but the amount of intracellular potassium had increased to a moderate degree, relative to the start of the experiment.

Exchanges of sodium. In Patient R. B., during recovery some sodium shifted from the extracellular to the intracellular phase at the same time that potassium was being taken up into both phases. In Patient D. D. there apeared to be a rough reciprocal relationship between sodium and potassium, the amount of cellular sodium increasing slightly during the initial diminution of cellular potassium, and an opposite relationship obtaining during the recovery period when potassium entered cells.

Potassium and sodium in erythrocytes. In $\mathrm{Pa}-$ tient D. D. the potassium and sodium contents of red blood cells were determined at the peak of paralysis (hour 62) and again following recovery (hour 74). A slight increase in the concentrations of sodium and potassium in water of red cells occurred during this interval. At both times, however, values were still below normal (17). 


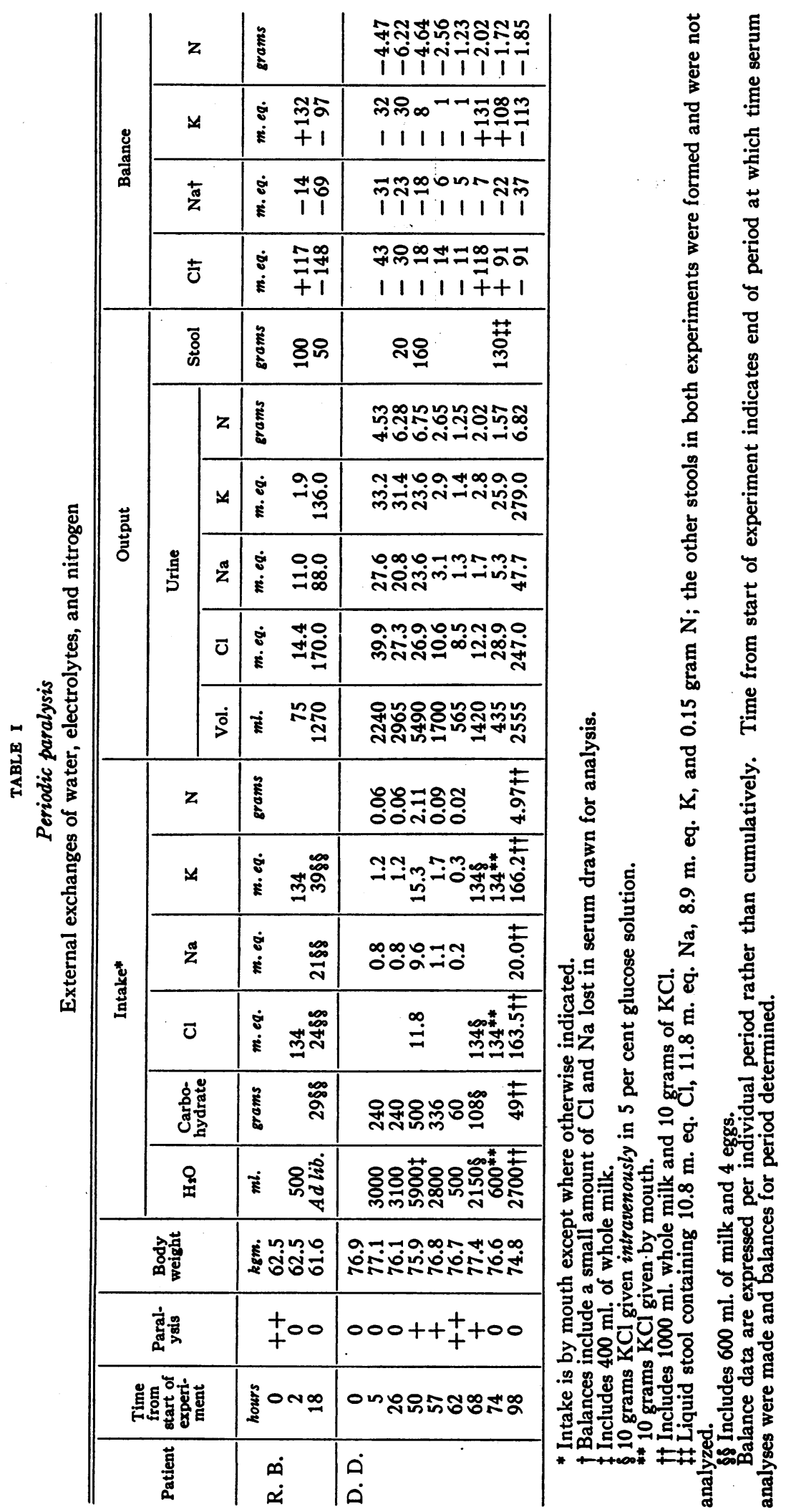


TABLE II

Periodic paralysis

Analyses of blood, serum, and red cells

\begin{tabular}{|c|c|c|c|c|c|c|c|c|c|c|c|c|}
\hline \multirow{2}{*}{ Patient } & \multirow{2}{*}{$\begin{array}{c}\text { Time from } \\
\text { start of } \\
\text { experiment }\end{array}$} & \multirow{2}{*}{ Paralysis } & \multicolumn{4}{|c|}{ Blood } & \multicolumn{4}{|c|}{ Serum } & \multicolumn{2}{|c|}{ Red cell $\mathrm{H}_{2} \mathrm{O}$} \\
\hline & & & NPN & Sugar & $\begin{array}{l}\text { Relative } \\
\text { cell vol. }\end{array}$ & $\begin{array}{l}\text { Hemo- } \\
\text { globin }\end{array}$ & $\mathrm{H}_{2} \mathrm{O}$ & $\mathrm{Cl}$ & $\mathrm{Na}$ & $\mathbf{K}$ & $\mathrm{Na}$ & $\mathbf{K}$ \\
\hline R. B. & $\begin{array}{c}\text { hours } \\
0 \\
2 \\
18\end{array}$ & $\begin{array}{c}++ \\
0 \\
0\end{array}$ & $\underset{\text { per cent }}{\operatorname{mgm} .}$ & $\underset{\text { per cent }}{\operatorname{mgm} .}$ & per cent & $\begin{array}{c}\text { grams } \\
\text { per cent }\end{array}$ & $\begin{array}{c}\text { grams } \\
\text { per liter } \\
* \\
* \\
*\end{array}$ & $\begin{array}{c}\text { m. eq. } \\
\text { per liter } \\
96.0 \\
100.8 \\
94.6\end{array}$ & 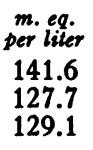 & $\begin{array}{c}\text { m. eq. } \\
\text { per liler } \\
2.3 \\
4.4 \\
4.4\end{array}$ & $\begin{array}{l}\text { m. eq. } \\
\text { per liter }\end{array}$ & $\begin{array}{l}\text { m. eq. } \\
\text { per liter }\end{array}$ \\
\hline D. D. & $\begin{array}{l}0 \\
5 \\
26 \\
50 \\
57 \\
62 \\
68 \\
74 \\
98\end{array}$ & $\begin{array}{c}0 \\
0 \\
0 \\
+ \\
+ \\
++ \\
+ \\
0 \\
0\end{array}$ & $\begin{array}{l}38 \\
31 \\
28 \\
31 \\
27 \\
28 \\
28 \\
28 \\
32\end{array}$ & $\begin{array}{l}76 \\
71 \\
84 \\
80 \\
80 \\
78 \\
73 \\
68 \\
-\end{array}$ & $\begin{array}{l}45.8 \\
40.9\end{array}$ & $\begin{array}{l}16.6 \\
15.6\end{array}$ & $\begin{array}{l}938 \\
936 \\
932 \\
929 \\
927 \\
936 \\
932 \\
942 \\
939\end{array}$ & $\begin{array}{l}103.8 \\
104.0 \\
102.7 \\
106.4 \\
102.6 \\
103.0 \\
109.0 \\
107.8 \\
106.6\end{array}$ & $\begin{array}{l}144.8 \\
143.5 \\
146.9 \\
148.0 \\
144.8 \\
147.0 \\
146.5 \\
144.3 \\
142.0\end{array}$ & $\begin{array}{l}4.3 \\
4.4 \\
4.0 \\
3.3 \\
2.9 \\
2.2 \\
3.5 \\
6.1 \\
4.8\end{array}$ & $\begin{array}{r}.0 \\
6.5\end{array}$ & $\begin{array}{l}116 \\
122\end{array}$ \\
\hline
\end{tabular}

* Water of serum!was assumed to be 930 grams per liter.

Exchanges of water. Changes in volume of ure the volume of extracellular fluid (14), was total body water and of extracellular and intracel- found to be 16.4 liters, or 21.4 per cent of the lular fluid were essentially negligible. In Patient body weight. Calculating backward by means of D. D. the volume of distribution of mannitol was the chloride balance, the extracellular fluid volumes determined after recovery (hour 74). At this at the peak of paralysis (hour 62) and at the bepoint the mannitol space, which appears to meas- ginning of the experiment (hour 0 ) were equiv-

TABLE III

Periodic paralysis

Calculated exchanges of water, sodium, and potassium between the extracellular and intracellular phases of body fluid

\begin{tabular}{|c|c|c|c|c|c|c|c|c|c|c|}
\hline \multirow{3}{*}{ Patient } & \multirow{3}{*}{$\begin{array}{l}\text { Time from } \\
\text { start of } \\
\text { experiment }\end{array}$} & \multirow{3}{*}{ Paralysis } & \multicolumn{3}{|c|}{ Change in volume of } & \multicolumn{4}{|c|}{$\mathrm{Na}$ and $\mathrm{K}$ balances for } & \multirow{3}{*}{$\begin{array}{l}\text { Change } \\
\text { in total } \\
\text { osmotically } \\
\text { active base }\end{array}$} \\
\hline & & & \multirow{2}{*}{$\begin{array}{l}\text { Total } \\
\text { body } \\
\text { water }\end{array}$} & \multirow{2}{*}{$\begin{array}{l}\text { Extra- } \\
\text { cellular } \\
\text { fluid }\end{array}$} & \multirow{2}{*}{$\begin{array}{l}\text { Intra- } \\
\text { cellular } \\
\text { fluid }\end{array}$} & \multicolumn{2}{|c|}{$\begin{array}{c}\text { Extracellular } \\
\text { phase }\end{array}$} & \multicolumn{2}{|c|}{$\begin{array}{l}\text { Intracellular phase in } \\
\text { excess of } N\end{array}$} & \\
\hline & & & & & & $\mathrm{Na}$ & $\mathbf{K}$ & $\mathrm{Na}$ & $\mathbf{K}$ & \\
\hline R. B. & $\begin{array}{c}\text { hours } \\
0 \\
2 \\
18\end{array}$ & $\begin{array}{c}++ \\
0 \\
0\end{array}$ & $\begin{array}{l}\text { liters } \\
+0.1 \\
-\end{array}$ & $\begin{array}{l}\text { liters } \\
+0.4 \dagger \\
-0.5 \dagger\end{array}$ & $\begin{array}{l}\text { liters } \\
-0.3 \\
-\end{array}$ & $\begin{array}{l}\text { m. eq. } \\
-123 \\
-47\end{array}$ & $\begin{array}{l}\text { m. eq. } \\
+29 \\
-2\end{array}$ & $\begin{array}{l}\text { m. eq. } \\
+109^{*} \\
-22^{*}\end{array}$ & $\begin{array}{l}\text { m. eq. } \\
+103^{*} \\
-95^{*}\end{array}$ & $\begin{array}{l}\text { m. eq. } \\
-758 \\
+116\end{array}$ \\
\hline D. D. & $\begin{array}{r}0 \\
5 \\
26 \\
50 \\
57 \\
62 \\
68 \\
74 \\
98\end{array}$ & $\begin{array}{c}0 \\
0 \\
0 \\
+ \\
+ \\
++ \\
+ \\
0 \\
0\end{array}$ & $\begin{array}{l}+0.3 \\
-0.7 \\
\pm 0 \\
+0.9 \\
\pm 0 \\
+0.8 \\
-0.5 \\
-1.3\end{array}$ & $\begin{array}{l}-0.5 \\
-0.1 \\
-0.5 \\
+0.4 \\
\pm 0 \\
\pm 0 \\
+1.1 \ddagger \\
-0.6\end{array}$ & $\begin{array}{l}+0.8 \\
-0.6 \\
+0.5 \\
+0.5 \\
\pm 0 \\
+0.8 \\
-1.6 \\
-0.7\end{array}$ & $\begin{array}{r}-88 \\
+49 \\
+79 \\
+15 \\
+13 \\
+\quad 2 \\
+103 \\
-120\end{array}$ & $\begin{array}{l}-1 \\
-6 \\
-13 \\
-5 \\
-12 \\
+22 \\
+46 \\
-24\end{array}$ & $\begin{array}{l}+57 \\
\pm \quad 71 \\
+62 \\
-21 \\
=18 \\
=\quad 9 \\
-125 \\
+84\end{array}$ & $\begin{array}{r}-29 \\
-13 \\
+\quad 20 \\
+\quad 5 \\
+15 \\
+114 \\
+66 \\
-79\end{array}$ & $\begin{array}{r}+43 \\
+163 \\
+76 \\
+\quad 3 \\
+46 \\
+\quad 6 \\
-326 \\
-150\end{array}$ \\
\hline
\end{tabular}

* These values represent the balance for the total intracellular phase ( $b_{\mathrm{N}_{\mathbf{1}}}$ and $b_{\mathrm{K}_{\mathbf{1}}}$ ) uncorrected for loss of nitrogen.

† Calculated from an initial extracellular volume $\left(E_{1}\right)$ taken to equal 20 per cent of the body weight.

$¥$ The volume of distribution of mannitol at this time was determined to be $16.4,15.6$, and 16.7 at $1,1 \frac{1}{2}$, and 2 hours, respectively, following the intravenous injection of 25.45 grams of mannitol.

Balance data are expressed per individual period rather than cumulatively. Time from start of experiment indicates end of period at which time balances for the period were determined. 


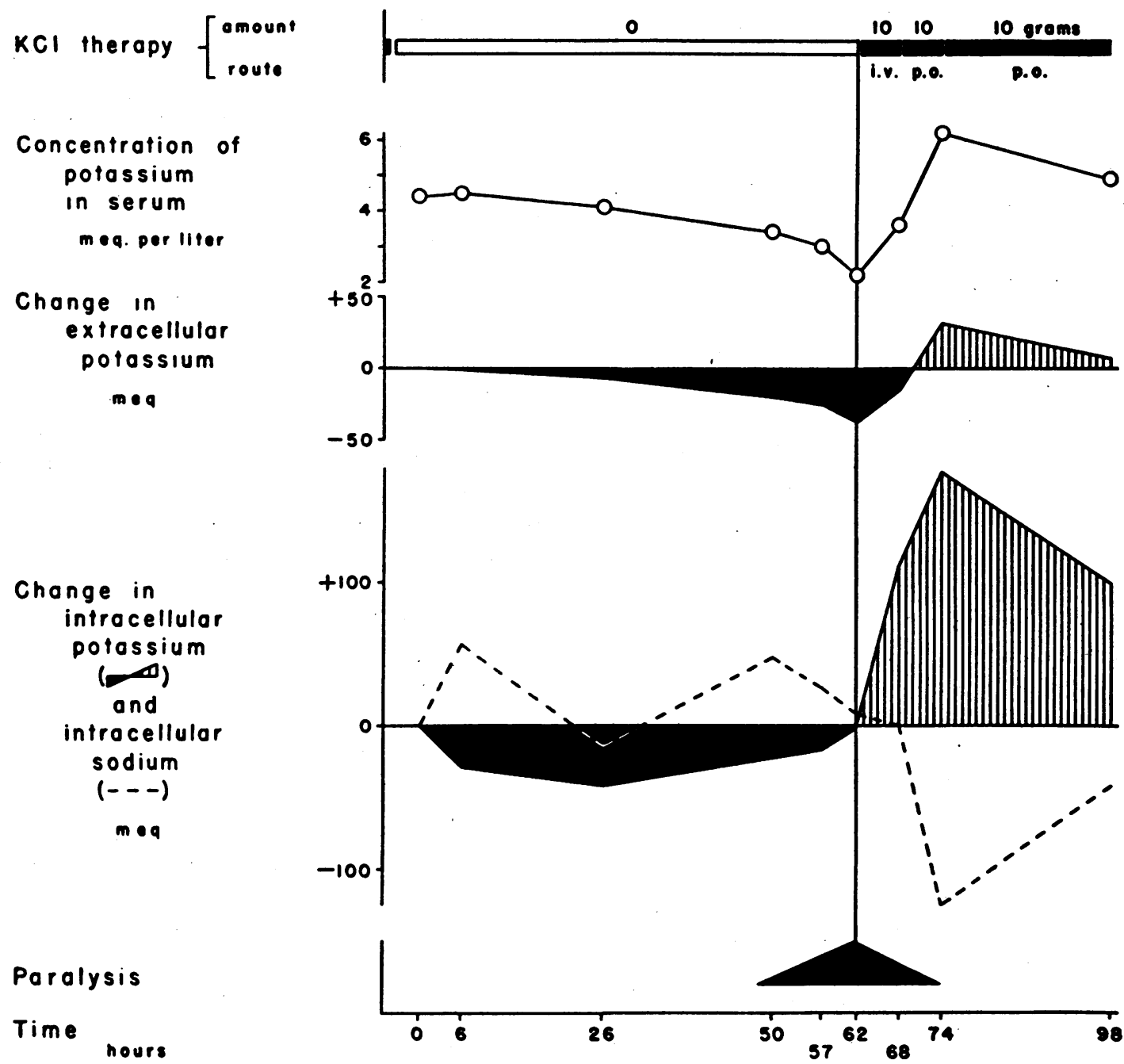

Fig. 1. Cumulative Exchanges of Potassium during the Induction and Treatment of an Attack of Periodic Paralysis (Patient D. D.)

Changes in extracellular potassium and intracellular potassium in excess of nitrogen are shown; the negative ones are solid black, the positive ones are lined vertically. The concentration of potassium in serum is plotted with open circles. The change in intracellular sodium is plotted with a broken line. The presence of paralysis is indicated by a solid black triangle at the bottom of the figure.

The data indicate that during the actual onset of paralysis, potassium moved from the extracellular to the intracellular phase. During treatment with $\mathrm{KCl}$, a positive balance of intracellular potassium was built up before the extracellular deficit was overcome. The change in cell sodium showed an inverse relationship to that of cell potassium.

alent to 20.0 and 21.1 per cent of the body weight, respectively. These values are of the order of magnitude of those accepted as normal for the extracellular phase (18).

The change in plasma volume which occurred between the peak of paralysis (hour 62) and recovery (hour 74) amounted to a relative increase of 17 per cent, as estimated from the hematocrit values and hemoglobin concentrations (19). This rise in plasma volume is not proportional to the increase of 1.1 liters in extracellular fluid (7 per cent), and hence suggests some redistribution of water between plasma and interstitial fluid during paralysis.

Changes in total osmotically active base. The discrepancies between the actual total balances of 
sodium plus potassium and the balances of total osmotically active "base" in the body, as calculated from the changes in volume of body water and extracellular sodium concentration, probably represent changes in osmotic activity of base ${ }^{4}$ within body cells (16). During the early period of depletion of cell potassium in Patient D. D., cell base appeared to have been activated. Conversely, during the recovery period when cells were taking up potassium, a large decrease in the osmotically active components of cells occurred in both patients.

Electrocardiographic alterations. In Patient R. B. the $T$ waves which were absent during paralysis returned and the minor changes in $\mathrm{S}-\mathrm{T}$ segments disappeared during recovery (hours 2 and 18). In Patient D. D. the inverted $T$ wave in lead 2 which was present during the paralysis reverted to an upright position at the time of partial recovery and to normal height in the upright position at the time of complete recovery. These changes are consistent with the known effect of low concentrations of serum potassium on the electrocardiogram (20).

\section{DISCUSSION}

Interpretation of the potassium transfers. These data clearly indicate that the movement of potassium immediately associated with the onset of muscular paralysis in this disease consists of a transfer of extracellular potassium into the intracellular phase. The result of this transfer is a striking depression of the extracellular concentration. It is not possible to identify, however, the portion of the cellular phase into which this potassium went. The balances as calculated are only for the overall phases of the intact organism and do not differentiate the distribution of electrolytes in the various tissues. Speculation on this point based on indirect evidence, however, is possible. The first possibility is that potassium has entered the cells of skeletal muscle which constitute the largest depot of potassium and the major portion of the intracellular phase. This site of the transfer is suggested by the experimental conditions which

4 This refers to the end-result, and does not exclude the possibility that the process is initiated by alterations in the osmotic activity or the base-binding capacity of celular anions. have produced diminution of extracellular potassium and paralysis in this disease. These conditions have been the administration of carbohydrate, of insulin, and of epinephrine (7). All of these substances are known to produce a lowering of serum potassium concentration (21 to 26 ), and all of them are associated with increased oxidation of carbohydrate in the muscles. It would seem reasonable, therefore, to ascribe the transfers of potassium which take place in periodic paralysis to the cycle of carbohydrate combustion in skeletal muscle. An alternate possibility, that the extracellular potassium shifts into the cells of liver in association with glycogenesis (27), is unlikely in view of the fact that insulin and epinephrine are predominantly glycogenolytic substances. Both D'Silva (28) and Gerschman (26) have shown that the transient initial rise in the concentration of serum potassium following the administration of epinephrine is abolished when the liver is excluded or removed. Epinephrine apparently promotes the transfer of potassium with glycogen from the liver to the muscles.

Whether or not the movement of extracellular potassium is into cells of skeletal muscle or into those of other tissues, there must be some difference between these patients and the normal individual with respect to replacement of the extracellular potassium deficit. One explanation would be that all the body cells of the patient with periodic paralysis contain a normal or an excessive amount of potassium owing to an abnormal avidity for this cation. Such an avidity, however, can hardly be explained by the binding of potassium to protein or organic phosphate complexes within the cell. The evidence in these experiments indicates that during the development of paralysis the osmotic activity of cell fluid is increased and conversely during recovery, is decreased. Besides, analysis of the relation of exchanges of sodium and potassium across the cell membrane to changes in osmotic activity of base within the cell, shows that there is little quantitative relationship between the two (29).

Another possibility is that the replacement of the extracellular potassium is prevented by a chronic deficit of muscle potassium. This is suggested by the fact that following treatment of $\mathrm{Pa}$ tient D. D.'s paralysis with intravenous $\mathrm{KCl}$ (hour 
68), 114 m.eq. of potassium had been taken up into the intracellular phase while a deficit of 15 m.eq. of extracellular potassium persisted and muscular weakness was still present. Unequivocal evidence for such a state of muscle potassium depletion is missing but suggestive evidence is as follows: Darrow (30) has analyzed muscle obtained at autopsy from 1 case and found the potassium content to be low. The muscle, however, was atrophic and the changes found were probably related to the postmortem state or the atrophy rather than to the periodic paralysis. Erythrocyte content of potassium has been shown to be lower than normal by other workers $(4,7)$ as well as in this study. Finally, the positive balance of 100 m.eq. of cell potassium in Patient D. D., at the end of the study, might suggest that the patient had a cell potassium deficit at the beginning of the experiment. However, these are all conjectural interpretations and it is very difficult to establish their validity, particularly since this balance represents an increase of only 1.3 m.eq. per kilogram of body weight, a relatively minor increment in muscle cell potassium.

Pathogenesis of the paralysis. Certain conclusions can be drawn from the quantitative data obtained concerning the relation of the potassium exchanges to the muscular paralysis. The paralysis cannot be directly due to an increase in potassium content of the muscle cells in general because of the relatively minute amount of potassium transferred from the extracellular fluid with the onset of paralysis. Depletion of muscle cell potassium could contribute to the mechanism only indirectly by preventing replacement of the extracellular potassium deficit. The paralysis must be due either to the depletion of extracellular potassium with the lowered concentration or to the presence of the displaced potassium in a special tissue. It is hard to see, however, how the latter disturbance would be relieved by administration of more potassium. The primary cause of the paralysis, therefore, probably lies in the loss of potassium from the extracellular fluid, with the low concentration producing an effect on the neuromuscular mechanism. The difficulty with such a simple explanation is the fact that paralysis is not always present with hypopotassemia in other conditions (31 to 33 ), nor does it correlate exactly with the fall in extracellular potassium concentration in this condition (7).

Specificity of the potassium defect. Depletion of extracellular potassium in association with the development of paralysis is certainly the chief physiological defect in this disease. However, this mechanism of paralysis is apparently not unique to this disease as the concurrence of hypopotassemia and muscular weakness has been reported in other clinical and experimental conditions. Ferrebee and co-workers (34) have shown that the administration to dogs of desoxycorticosterone, when potassium was withheld, produced deficits of muscle potassium ranging from 35 to 66 per cent of the initial content; replacement of the cell potassium by sodium; lowering of the extracellular potassium concentrations; and muscular weakness and paralysis. Holler (35) described muscular paralysis associated with hypopotassemia in a case of diabetic acidosis undergoing treatment with large amounts of glucose and insulin. It is well known that deficits of cellular potassium occur in this condition $(36,37)$. A similar association of muscular weakness with hypopotassemia has been reported in chronic nephritis (38) and in sprue (39).

In these other conditions the existence of deficits of cellular potassium has been established. Whether or not similar deficits exist in familial periodic paralysis, and what role they play in the disease is not known. The common denominator, however, appears to be the diminution in concentration of extracellular potassium.

\section{SUM MARY}

1. Potassium, sodium, and water exchanges were studied in 2 patients with periodic paralysis.

2. During the development of paralysis, potassium shifted from the extracellular to the intracellular phase with a resultant sharp decline in the extracellular potassium concentration.

3. During recovery large amounts of administered potassium were taken up by the intracellular phase before the extracellular potassium was replenished.

4. Reciprocal transfers of cell sodium were observed in 1 case but not in the other.

5. No significant changes occurred in the volumes of total body water and extracellular fluid. 
6. Cellular processes which might effect the transfer of potassium are discussed.

7. It is concluded that the diminution in extracellular concentration of potassium is responsible for the development of paralysis.

\section{BIBLIOGRAPHY}

1. Biemond, A., and Daniels, A. P., Familial periodic paralysis and its transition into spinal muscular atrophy. Brain, 1934, 57, 91.

2. Aitken, R. S., Allott, E. N., Castleden, L. I. M., and Walker, M. B., Observations on a case of familial periodic paralysis. Clin. Sc., 1937, 3, 47.

3. Allott, E. N., and McArdle, B., Further observations on familial periodic paralysis. Clin. Sc., 1938, 3, 229.

4. Pudenz, R. H., McIntosh, J. F., and McEachern, D., The role of potassium in familial periodic paralysis. J. A. M. A., 1938, 111, 2253.

5. Ferrebee, J. W., Atchley, D. W., and Loeb, R. F., A study of the electrolyte physiology in a case of familial periodic paralysis. J. Clin. Invest., 1938, 17, 504.

6. Gammon, G. D., Austin, J. H., Blithe, M. D., and Reid, C. G., The relation of potassium to periodic paralysis. Am. J. M. Sc., 1939, 197, 326.

7. Talbott, J. H., Periodic paralysis; a clinical syndrome. Medicine, 1941, 20, 85.

8. Ferrebee, J. W., Gerity, M. K., Atchley, D. W., and Loeb, R. F., Behavior of electrolytes in familial periodic paralysis. Arch. Neurol. \& Psychiat., 1940, 44, 830.

9. Sherman, H. C., Chemistry of Food and Nutrition. The MacMillan Co., New York, 1941, Ed. 6.

10. Hald, P. M., The determination of the bases of serum and whole blood. J. Biol. Chem., 1933, 103, 471.

11. Butler, A. M., and Tuthill, E., An application of the uranyl zinc acetate method for the determination of sodium in biological material. J. Biol. Chem., 1931, 93, 171.

12. Hald, P. M., The flame photometer for the measurement of sodium and potassium in biological materials. J. Biol. Chem., 1947, 167, 499.

13. Elkinton, J. R., and Taffel, M., Prolonged water deprivation in the dog. J. Clin. Invest., 1942, 21, 787.

14. Elkinton, J. R., The volume of distribution of mannitol as a measure of the volume of extracellular fluid. With a study of the mannitol method. J. Clin. Invest., 1947, 26, 1088.

15. Elkinton, J. R., and Winkler, A. W., Transfers of intracellular potassium in experimental dehydration. J. Clin. Invest., 1944, 23, 93.

16. Elkinton, J. R., Winkler, A. W., and Danowski, T. S., Inactive cell base and the measurement of changes in cell water. Yale J. Biol. \& Med., 1944, 17, 383.

17. Hald, P. M., Notes on the determination and distri- bution of sodium and potassium in cells and serum of normal human blood. J. Biol. Chem., 1946, 163, 429.

18. Gamble, J. L., Extracellular fluid. Buhl. Johns Hopkins Hosp., 1937, 61, 151.

19. Elkinton, J. R., Danowski, T. S., and Winkler, A. W., Hemodynamic changes in salt depletion and in dehydration. J. Clin. Invest., 1946, 25, 120.

20. Stewart, H. J., Smith, J. J., and Milhorat, A. T., Electrocardiographic and serum potassium changes in familial period paralysis. Am. J. Med. Sc., 1940, 199, 789.

21. Flock, E. V., Bollman, J. L., Mann, F. C., and Kendall, E. C., The effect of the intravenous injection of glucose and other substances on the concentration of potassium in the serum of the dog. J. Biol. Chem., 1938, 125, 57.

22. Keys, A., The effect in men and dogs of massive doses of insulin on the composition of blood serum. Am. J. Physiol., 1938, 123, 608.

23. D'Silva, J. L., Action of adrenalin on the serum potassium. J. Physiol., 1937, 90, 303.

24. Castleden, L. I. M., The effect of adrenalin on the serum potassium level in man. Clin. Sc., 1938, 3, 241.

25. Keys, A., The response of the plasma potassium level in man to the administration of epinephrine. Am. J. Physiol., 1938, 121, 325.

26. Gerschman, R., El Potassio Plasmatico En El Estado Normal Y En El Pathologico. Buenos Aires, 1939.

27. Fenn, W. O., The deposition of potassium and phosphate with glycogen in rat livers. J. Biol. Chem., 1939, 128, 297.

28. D'Silva, J. L., The action of adrenalin on serum potassium. J. Physiol., 1936, 86, 219.

29. Elkinton, J. R., Winkler, A. W., and Danowski, T. S., Transfers of cell sodium and potassium in experimental and clinical conditions. J. Clin. Invest., 1948, 27, 74.

30. Darrow, D. C., personal communication.

31. Ferrebee, J. W., Ragan, C., Atchley, D. W., and Loeb, R. F., Desoxycorticosterone esters; certain effects in the treatment of Addison's disease. J. A. M. A., 1939, 113, 1725.

32. Willson, D. M., Power, M. H., and Kepler, E. J., Alkalosis and low plasma potassium in a case of Cushing's syndrome: metabolic study. J. Clin. Invest., 1940, 19, 701.

33. Butler, A. M., Talbot, N. B., and MacLachlan, E. A., Effect of testosterone therapy on concentration of potassium in serum. Proc. Soc. Exp. Biol. \& Med., 1942, 51, 378.

34. Ferrebee, J. W., Parker, D., Carnes, W. H., Gerity, M. K., Atchley, D. W., and Loeb, R. F., Certain effects of desoxycorticosterone; the development of "diabetes insipidus" and the replacement of muscle potassium by sodium in normal dogs. Am. J. Physiol., 1941, 135, 230. 
35. Holler, J. W., Potassium deficiency occurring during the treatment of diabetic acidosis. J. A. M. A., $1946,131,1186$.

36. Atchley, D. W., Loeb, R. F., Richards, D. W., Jr., Benedict, E. M., and Driscoll, M. E., On diabetic acidosis; a detailed study of electrolyte balances following the withdrawal and reestablishment of insulin therapy. J. Clin. Invest., 1933, 12, 297.

37. Butler, A. M., Talbot, N. B., Burnett, C. H., Stanbury, J. B., and MacLachlan, E. A., Metabolic studies in diabetic coma. Trans. Assoc. Am. Physicians, 1947, in press.

38. Brown, M. R., Currens, J. H., and Marchand, J. F., Muscular paralysis and electrocardiographic abnormalities resulting from potassium loss in chronic nephritis. J. A. M. A., 1944, 124, 545.

39. Harrison, H. E., Harrison, H. C., Tompsett, R. R., and Barr, D. P., Potassium deficiency in a case of lymphosarcoma with the sprue syndrome. Am. J. Med., 1947, 2, 131. 